D'autre part, en liaison avec la Section, M. Guy Le MOAL va entreprendre en Haute-Volta une étude sur les migrations de main-d'œuvre Mossi et sur le rôle des travailleurs migratoires comme éléments de transformation de la société Mossi.

La Section de Sociologie demeure enfin en contact avec des chercheurs engagés dans des travaux particuliers, comme M. Bohumil Holas, qui, en Côte d'Ivoire, poursuit ses recherches sur les problèmes religieux.

\title{
Carnegie Corporation's Grant for Social Research in South Africa
}

THe Carnegie Corporation of New York has made available about $£ 7,500$ to the National Council for Social Research, under the Department of Education, Arts, and Science, for fellowships for the training of advanced social research workers at the University of Natal, according to an official statement. The Corporation has also offered to provide the necessary funds during 1954 for the appointment of two American scientists at the university to assist with the project. This is not the first time the Carnegie Corporation has taken an interest in social research in South Africa. In 1927 the Corporation provided funds for investigations into the conditions of 'poor whites'. Funds have also previously been given for the activities of the South African Council for Educational and Social Research.

The statement issued by the Department of Education says that South Africa has a number of urgent social problems to investigate and solve, but it is handicapped by a dearth of highly trained staff to plan, direct, and conduct such investigations according to the latest scientific techniques. These techniques usually involve team work between workers in sociology, economics, psychology, education, social anthropology, and allied subjects. The contemplated project for the training of advanced social research workers will include problems in all these fields.

The administration of funds and general direction of the project, which has been initiated by Dr. E. G. Malherbe, principal of the University of Natal, will be undertaken by the ad hoc committee, consisting of members of the staff of the University and representatives of the National Council for Social Research.

\section{University College for Central Africa}

THE immediate foundation of a University College as a first step towards a full university in Central Africa is recommended by the Report of the Commission on Higher Education for Africans in Central Africa, published by the Central African Council, Salisbury, Southern Rhodesia.

The report was prepared by a Commission set up by the Central African Council. The members of the Commission were Sir Alexander Carr-Saunders, Director, London School of Economics (Chairman), Mr. A. V. Hill, Emeritus Professor of Physiology, London University, Dr. Alexander Kerr (formerly Principal, South African Native College, Fort Hare, now the University College of Fort Hare), Dr. F. G. Young, Professor of Biochemistry, Cambridge, and Mr. Walter Adams, Secretary, Inter-University Council for Higher Education in the Colonies.

The Report recommends that the University College should be created by Royal Charter, and that in preparing its constitution the constitutions of the new universities in Britain should be followed. Application should be made by the College to be received into 'special relations' with the University of London. The Commission points out that it is contrary to university tradition to have regard to race, religion or class when selecting candidates for admission. It is not in itself contrary to university practice to reserve certain hostels 
for particular categories of students, but all should share teaching and laboratory facilities and be admitted to membership of the Students' Union.

\section{Recherche scientifique en Madagascar}

L'INstrTur de Recherche Scientifique de Madagascar, rattaché à l'Office de la Recherche Scientifique Outre-Mer, fut créé en 1946 par le professeur Millot, du Muséum National d'Histoire Naturelle de Paris, qui en conserve toujours la direction, assisté de son adjoint le Dr. Pauliau. Il a été édifié au pied des escarpements de Tananarive sur la pente dominant le vallon de Tsimbazaza.

Dans le bâtiment principal sont réunis les bureaux, la bibliothèqué, les laboratoires de biologie, de botanique, d'ethnologie, de chimie végétale et de parasitologie. Le sous-sol est organisé en salle de conférences. L'ancien jardin zoologique et botanique a été annexé à l'Institut. La section d'ethnographie est la dernière créée. Des fouilles ont été effectuées dans les nécropoles islamiques du nord-est et, d'autre part, l'ethnologue procède actuellement à une étude sociologique de la population Tsimihety. Des collections d'objets sont recueillies, destinées à un musée d'ethnographie dont la construction est prochaine.

\section{'Centre Africain' de l'Université Franco-Belge de New-York}

LE 'Centre Africain' a clôturé sa première année d'activité. Pendant cette période le professeur Jean Maynard a dirigé un séminaire en anglais sur l'Afrique contemporaine, suivi par 17 étudiants, et le professeur Jean Comhaire a donné un cours en français sur l'histoire de l'Afrique, suivi par 2 I élèves. Diverses personnalités ayant une grande expérience des questions africaines ont participé à ces travaux, notamment M. Goiran, ancien ministre de France en Afrique du Sud, M. Sieck, ancien vice-consul de Suisse à Dakar, et le Père de Pauw, ancien missionnaire franciscain au Katanga.

\section{Union Internationale pour la Protection de la Nature}

A PAMPHLET prepared with the assistance of UNESCO and distributed by IFAN, Dakar, sets forth the aims of the U.I.P.N., which was founded in 1948 for the purpose of securing the collaboration of governments, administrations, international and national institutions in the protection of the land, of wild fauna and birds, and of plants. Its particular subjects of study are the use or abuse of natural resources, the dangers of deforestation, the extermination of natural species by unregulated hunting and fishing, the destruction of indigenous vegetation and the introduction of unsuitable exotic species. Meetings of the Union were held in 1950 at Brussels, in 1952 at Caracas in Venezuela, as a result of which recommendations have been made to the governments of more than 25 countries. A volume of 538 pages entitled Etat de la Protection de la Nature dans le monde en 1950 was published under the auspices of the Union, a Bulletin d'information, in French and English, is published every two months by the Secretariat, and toneoed pamphlets are issued periodically by IFAN, Dakar; a commission on Public Information has been established in Washington, D.C. The Secretary General of the Union is M. Harroy, 42 Rue Montoyer, Brussels, Belgium. 